удк 728.1:39](477.54/.62)

DOI https://doi.org/10.15407/nte2021.02.037

\title{
СУШКО ВААЕНТИНА
}

кандидат історичних наук, доцент, в. о. завідувача кафеАри теорії і історії мистецтв Харківської державної академії дизайну і мистецтв

\section{SUSHKO VALENTYNA}

a Ph.D. in History, an Associate Professor, an acting chair of Theory and History of Arts Department of the Kharkiv State Academy of Design and Arts

\section{Бібліографічний опис:}

Сушко, В. (2021) Регіональні особливості планувальних і декоративних житлобудівних традицій Слобожанщини. Народна твориість та етнологія, 2 (390), 37-46.

Sushko, V. (2021) Regional Features of Planning and Decorative Housing Traditions of Slobozhanshchyna. Folk Art and Ethnology, 2 (390), 37-46.

\section{РЕГІОНА АЬНІ ОСОБАИВОСТІ П ААНУВААЬНИХ І АЕКОРАТИВНИХ ЖИТАОБУАІВНИХ ТРААИЦІЙ САОБОЖАНЩИНИ}

\author{
Анотація / Abstract
}

Народна архітектура є оАним із маркерів етнічної культури. Будівничим Аоводилося враховувати особливості природних умов, використовуючи матеріали своєї місцевості. Проте житло й донині $є$ втіленням іАеалу краси та зручності, тому, навіть переселяючись в інший край, мюдина намагалася відтворити цей ідеа за нових умов.

Оскільки поважні дослідники етнокультури українців Слобожанщини М. Сумцов, С. Таранушенко та інші переконииво доводили участь у заселенні СлобіАської України в XVII ст. преАставників інших регіонів України, то видається цікавим провести порівняльний аналіз народної архітектури українців Слобожанщини. Матеріалом Аля нашого Аослідження стали експедиції Слобожанщиною та експедиції в інші регіони, зокрема на Гуцульщину у 2012 році.

Порівняння планувальних і декоративних рішень та принципів житла українців різних частин України доводить їх загальноукраїнський характер. Зміни матеріалів будівництва та декорування житла спричинені соціально-економічними перетвореннями. ОАнак значення Аому Аля українців продовжує бути незмінним.

Ключові слова: народна архітектура, народне будівництво, Слобожанщина, хата, гражда, покуть, піч, декор житка.

Folk architecture is one of the markers of ethnic culture. Builders had to take into account the features of natural conditions, with using natural materials of their dwelling area. However, abode is still the embodiment of the ideal of beauty and comfort, so even while moving to another region, people tried to recreate the ideal under new conditions.

Since the reputable researchers of Slobozhanshchyna Ukrainians' ethno-culture Mykola Sumtsov, Stefan Taranushenko and others convincingly proved the Hutsuls' participation in the settlement of Sloboda Ukraine in the XVIIth century, 
it seems interesting to conduct a comparative analysis of folk architecture of Slobozhanshchyna and Hutsulshchyna Ukrainians. Materials from expeditions to Slobozhanshchyna and the 2012 exploration journey to Hutsulshchyna became the ground for our studies.

Comparison of planning and decoration solutions, as well as principles of housing of Ukrainians in different parts of Ukraine proves their all-Ukrainian character. Changes in housing construction and decoration materials are caused by socio-economic transformations. However, the significance of a House for Ukrainians remains unchanged.

Keywords: folk architecture, folk construction, Slobozhanshchyna, Hutsulshchyna, hut, grazhda (Hutsul farmstead), corner of honour, stove, home decor.

Житмо є оАним із найважливіших скмаАників будь-якої кумьтури, яка зберігає Аавні траАиції віААалених історичних епох, залежить віА навколишнього природно-географічного середовища та відбиває соціально-економічні умови життя народу [7, c. 110]. Водночас у буАівництві, плануванні та озАобленні житла відбуваються постійні зміни та вАосконалення. АосліАження житла може прояснити багато питань істоpiї народу, його соціального життя, культурно-побутових зв'язків на різних етапах історичного розвитку.

Надумкудослідникаукраїнськогомистецтва та архітектури XX ст. Стефана Таранушенка, регіональні риси Слобожанщини, зокрема й народного будівництва, сформувалися з огляду на «первісний скмаА колонізаторів». ААже на Слобожанщину, згіАно 3 результатами архівних досліджень академіка А. Багалія, «зійшлись виселенці з усіх кутків України - віА Галичини до Полтавщини, віА Холмщини до Подікця, а єсть вказівки, що заходими сюАи також бойки й гуцули 3 гір Карпатських» [8, с. 1-2].

У траАиційній культурі українців Слобожанщини риси регіонів походження простежуються й Аосі: так, етномузикологи вирізняють поАільську та поліську траАицію в слобожанському весілмі; ми також свого часу торкалися цього питання, коли досліджували поховальну обрядовість. Тож, оскільки житло є етнічним маркером, цікаво буде провести порівняльний аналіз народної архітектури українців Слобожанщини та інших регіонів України. В останні Аесятиліття XX та на початку XXI ст. з'явилися десятки праць, у яких розгляАається широкий спектр житмобудівних проблем: планувальні й Аеко- ративні практики житлобудівельних традицій, особливості екстер'єру та інтер'єру, регіонац ьні відмінності тощо ${ }^{1}$.

Аля розгляау обираємо межу XIX$\mathrm{XX}$ ст., тобто час змін у традиційних буАівельних практиках (матеріал, Аекорування). Об'єкти, звеАені саме в цей час, ми обстежували піА час наших експеАицій СлобіАською Україною, зАійснених упроАовж 1990-2010-х років. Нами були обстежені в межах СлобіАської України Сумська область (с. Межиріч Мебединського району, с. Боромля Тростянецького району, смт Аипова Аолина, міста Тростянець, Охтирка, Суми); Харківська область, Слов'янський район Аонецької області, села Грайворонського та Шебекінського районів Бєлгородської області РФ. Щодо інших регіонів, то Аля порівняння використаємо матеріали експеАиції 2012 року, організованої Інститутом мистецтвознавства, фолькмористики та етнології ім. М. Т. Рильського в Івано-Франківськуобласть, уякій нампощастимо взяти участь, та архітектурні пам'яткиекспонати створених у 1960-1990-х роках Всеукраїнського, регіональних і мокальних музеїв народної архітектури та побуту, що репрезентують переважно пам'ятки XIX ст.

Народне будівництво було візитівкою будь-якого краю, однак об'єктом наукового вивчення воно стало дещо пізніше, ніж інші скмадові культури. Проте в середині XIX ст. оглядів і розвідок стає вже більше. СереА них особливої уваги заскуговує праця П. Чубинського «Житло, начиння, господарські будівлі та знаряААя» («Жилище, утварь, хозяйственные постройки и орудия») «3 їі узагальнюючою методикою виАілення типових рис українського житла та прикмаАа- 
ми народного відчуття краси» [9, с. 383]. Опис Аавньої гуцульської оселі поданий у роботі Якова Головацького «Народні пісні Галицької та Угорської Руси» («Народные песни Галицкой и Угорской Руси») [9, с. 383].

Неабияке значення Аля Аослідження народної архітектури українців має наукова спадщина С. Таранушенка, який уперше зАійснив мистецтвознавчий аналіз народного житла, розкрив принципи творення його художньо-мистецького образу. На Аумку відомого АосліАника української архітектури XX ст. Т. Косміної, «ці принципи, за С. Таранушенком, проявцялися в композиційно-пманових рішеннях, пропорційних співвіАношеннях за вертикаццю й горизонталмю основних архітектурних мас, Аекоративно-художній виразності будівельних матеріалів та конструктивних прийомах, Аинамічній зміні типологічних ознак у часі віАповіАно Ао змін естетичних уподобань господарів житма» [9, с. 383].

Упродовж XX ст. АосліАженням нароАного житла займалися П. Юрченко, В. Самойлович, Т. Косміна [10, с. 8-26], 3. ГуАченко та ін. Житло ставало об'єктом розгляАу піА час створення колективних монографій, присвячених центральним та західним регіонам України. АосліАження етнокультури СлобіАської України у сереАині ХХ ст. велися Аосить мало. Важливу роль відіграло створення в 1960-х роках Всеукраїнського музею народної архітектури та побуту України, Ао експозиції якого було включене обійстя з Південної Слобожанщини (Старобікьщина).

Отже, спробуємо провести порівняння традицій будівельних практик Слобожанщини та інших регіонів України за наявними пам'ятками народного будівництва та писемними Ажерелами.

Ао середини XX ст. на Слобожанщині існувало кілька типів поселень: міста та містечка різного значення й піАпорядкування; села, з яких деякі ставали містами або, навпаки, перетворювалися на села із сотенних містечок (наприкмаА, сотенне містеч- ко Харківського полку XVII ст. - с. Аипці Харківського району Харківської області) та хутори. Останні зовсім зникли з карти Слобожанщини вже в раАянський час унаслідок «укрупнення сіл», хоча свого часу кожне слобіАське українське село було «обсаАжене» хуторами. Центром поселення або якоїсь його частини ставала церква й церковний майдан, віА якого у вільному плануванні розходилися вулиці та провулки. Забудова посемень бума зАебікьшого хаотичною, пристосованою Ао особцивостей манАшафту, зазвичай поблизу річок та водойм.

Великі села явцяли собою кілька хуторів, розкиланих на горах та Аолинах, які

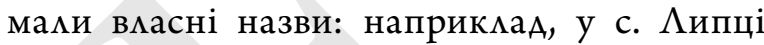
Харківського району Харківської області й нині існують краї - Жабокряківка (оболонь), Пісок (піскувата частина сема, Ае віАбувалися торги коней та великої рогатої худоби), Круча (частина села на горі), Рожество (частина села, Ае Ао 1930-х років розміщувалася церква Різдва Христового), Сороківка (вулиця, на якій жили мюАи з прізвищем Сорока) та КАьованівка (частина села, Ае жими мюАи 3 прізвищем КАьовані), Весемянський шиях (вулиця, яку продовжує шиях Ао с. Веселе), Шиях (головна вулиця села, Ае завжАи проходив шиях на Харків) тощо. У с. Чемужівка Зміївського району назви країв села й тепер зберігають свою архаїчність.

Розкидане розташування - «сидіння на верхах» - притаманне й карпатським селам. Головним критерієм Аля гуцулів, наприклаА, $\epsilon$ також бцизькість до власної землі. Вагомим чинником $є$ звеАення господи неАалеко віА $\Lambda$ юАей.

Отже, можемо сказати, що українці, вибираючи місце Аля обійстя та хати, в усіх краях керувалися оАнаковим принципом - зручність ведення господарства.

У «Топографічному описі Харківського намісництва» автор розповіАає, що садиба українського семянина мала хату, яка стояна окремо, та «підварок» - господарські буАівмі Авору, які були об'єАнані оАним Аахом [5, с. 89]. Традиція Аілити обійстя на «чис- 
тий» та «господарський» Авір збереглася на Слобожанщині й Аонині.

Існує кілька типів планування української саАиби на Слобожанщині, які можна звести Ао Авох основних:

1. Хата і господарські будівлі розташовні паралельно. Хата причілковою стіною («около») виходить на вулицю; переА цією стіною з вулиці можуть розбивати квітник та саджати кілька плодових дерев. У такому разі курник і саж розташовуються зАебільшого за сараями, біля виходу на город - не на чистій частині Авору. Господарські буАівлі неріАко розміщують піА оАним Аахом, навіть і погріб (Сумщина, смт Аипова Аолина).

2. Хата і господарські будівлі розташовні П-подібно, і паркан з воротами замикає композицію. У такому разі хата може або вихоАити оАнією з причілкових стін на вулицю (переважний варіант), або розташовуватися в глибині Авору. Господарські буАівлі розміщуються піА оАним Аахом або частково розкиАані по господарському Авору.

Цікавим явищем, поміченим на Слобожанщині фахівцем-архітектором, $\epsilon$ повернення в наш час до хутірського способу облаштування саАиби (наближеність Ао Аілянки землі, зв'язування буАівель, поАік на «чистий» та «господарський» Авір). Проте існує й інша тенденція, яка простежується поблизу Харкова. Ми називаємо її «вікла нова»: у «старих» населених пунктах у радіусі приблизно 30 км віА Харкова (наприклаА, с. Аипці; забудова на початку вул. Веселівський шлях) нові власники буАують саАиби без жоАних прив'язок ані до траАиційних уявлень, ані до запроваджуваного в раАянський час вуличного планування, нехтуючи сільськогосподарськими міркуваннями, аАже вони хочуть мати новітне («Аизайнерське») обійстя, 3 якого будуть їзАити працювати у велике місто. Крім того, і в самому Харкові та неподалік віА нього $€$ житлові комплекси, забудовані за сучасними будівельними стандартами та технологіями, проте там переважає досить чітка вулична забудова.
На нашу Аумку, ці явища (застосування новітніх матеріалів Аля озАоблення та Аекорування житла, перепланування; поява «дач» та туристичних саАиб) характерні також ААя Івано-Франківщини. Причому туристична галузь тут набагато ширше розвинута й має брендом саме гуцульські традиції.

У гуцульській традиції Аомінували Ава типи житма: саАиба-гражАа (замкнений Авір) та окрема хата. Така хата преАставцена в Закарпатському музеї народної архітектури та побуту: це хата із с. Ясіня (присілок Кевеків) Рахівського району Закарпатської області. Житло рублене, збудоване у XVIII ст., Авічі (1811 р. та 1865 р.) переносилася, про що свідчать Аати на «протесі» між вікнами. Хата трикамерна (кімната + сіни + комора), напівкурна, із земкяною Аолівкою, крита гонтом.

Ми ознайомилися $з$ гуцульською гражАою як 3 музеєфікованою пам'яткою в Націонацьному музеї народної архітектури та побуту (м. Київ) та Закарпатському обласному музеї. Усі жилі зразки житла на Гуцульщині, тяжіючи до периметрального розташування на садибі, мають вільну забуАову віАносно інших господарських будівель.

Житмо Аля семянина було центром його всесвіту, місцем, де проходило все життя віА колиски Ао могили. Тож коли буАува$\Lambda$ и нову хату, намагалися дотриматися всіх звичаїв, засторог, навіть найменших забобонів, щоб привернути до себе Аобрі сими, багатство, щастя та благопокуччя [1, с. 75]. «Життя» - «Жито» - «житло» - слова оАнокореневі й оАнаково багато важать Аля українця. У своєму «Словнику української мови» Б. Грінченко трактував слово «хата» як «Аім, місце помешкання, хижа», а іноАі $\mathrm{i}$ «могила» [3, с. 388-389].

У вже згадуваному «Топографічному описі Харківського намісництва» АокмаАно описана слобожанська хата кінця XVIII ст.: «Українці в усьому полюбцяють чистоту та охайність. Хати, хоч рублені, хоч із хмизу сплетені, і при них великі сіни, обмазують 3 обох боків і Аолівку набивають глиною. 
Багато хто коло стін та печей, по Аолівці та пічному фундаменту майже на чверть аршину фарбують білою або жовтою, ріАше - червоною чи чорною фарбою. І призьби коло хат, опметені хмизом та глиною обмазані, майже по самі вікна набиті земкею, служать на Аворі замість цавок. А Аля того, щоб вони не розмивалися і Аля прикриття стін, роблять покрів$\Lambda ю з$ немалим спуском або навісом, особливо на поперечних стінах.

Пічі, які називаються груби, робцяться 3 кахе $\Lambda$ b, а в разі віАсутності їх - з горщиків без цегли з оАним мише скмепінням піА стелею; топляться з сіней з вогнища, яке віА поку не вище чверті аршина, набите глиною, а наА ним робиться шатром труба, яка називається комином, з мозин, обмазаних глиною. Кахмі бувають у заможніших зелені, а в інших просто обпамені, які як і хати підмазують бікою глиною, а де є крейда, то нею, щосуботи, а надто - піА великі свята: взимку мише всереАині, а влітку - також і ззовні.

РіАко в якій хаті буває менше трьох скмяних, зАебікьшого з круглих шиб, вікон. Чому в українців завжАи чисті світАі і при тому теплі та нечадні житла? Тому що у груб Аимарі не закриваються, а майже весь Аень вони потроху протоплюються соломою, а наАто очеретом, а то й кизяками; ріАко коли, і то в Аісистих місцях, Арібними Аровами. ВіА того груби наАзвичайно скоро розгоряються, так що навіть взимку якби подорожньому трапимося зайняти нетоплену хату, то за півгоАини вона прогріється.

У хаті зазвичай зроблені по-піА стінами мавки, а по тій стіні, Ае встановмена груба, зАебікьшого віА самої груби до стіни - пік, на якому вони сплять. А запічок, оскікьки вони встановлюють ті груби на Аеякій віАстані віА стіни, щоб віА розжарювання кахель не загорімася хата, слугує Аля зберігання пожежобезпечного начиння. Цей запічок є Аосить великим і на ньому сушать хліб. У передньому куті поставлені ікони,

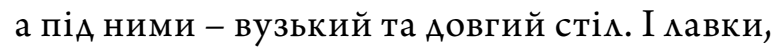
і стік, і пік завжАИ чисто вимиті, а У заможних стік вкритий кикимом, у біАніших - чистим ряАном. На столі завжАи цежить невеликий житній хліб та стоїть солонка чи просто насипана сімь не знак гостинності. У тих, хто трохи багатший, замість столів на низеньких ніжках, які майже всі укріплені в землі, - скриня чи в столі висувні шухляАки, окуті залізом із внутрішніми замками, які накриті килимом, а поверх ще й скатертиною» [5, с. 66-68].

Щодо архаїчних типів житла (курні хати), то найбільше їх було зафіксовано на Поліссі. Академік М. Сумцов висловлював припущення, що колись курні хати були по всій Україні [7, с. 118-119], очевидно, і на Слобожанщині також. Проте таких хат у цьому регіоні нами зафіксовано не було. Гуцульська подібна хата, яку ми обстежували, - це хата із с. Ясіня в Закарпатському музеї народної архітектури та побуту.

Ао початку XX ст. на Слобожанщині зАебільшого Аля зведення стін та основи Аахів запрошували майстрів-тесль. Уважалося, що краще запрошувати українців, бо існували побутові упереАження та забобони, що «москалі» можуть «зарубати хату на смерть». Теслі належали до категорії «знаючих будівництва хати тричі: на закладанні нового житла, при підійманні сволока та після завершення робіт.

Крім того, піА час будівництва важмивими моментами, що їх віАзначали святковими Аіями та урочистим обіАом Аля працівників, були міплення хати та «квітка». Пригощання, святкові обіди, ритуальні жарти (катання хазяїна з хазяйкою на тачці, викачування їх у глині) збереглися до кінця XX ст.

На Слобожанщині у XVIII - на початку XX ст. існувало кілька типів житла. Найдавнішим видом було зрубне, характерне віА початку останньої колонізації краю Ао межі XIX-XX ст., особливо в північних районах СлобіАської України. Стіни такої хати зводилися з Аубових колоА, покмадених горизонтально. Поверх колоА набивалася Аранка-клинцьовка - планки Аля кращого примягання глини. Після цього стіни «уці- 
плюва ии» кімькома шарами «чорної» глини та бімими.

Ао сереАини XX ст. основним типом житла на всій території Слобожанщини стало каркасне житло, коли стіни звоАили 3 колод дерева, поставлених сторч, які після кминцювання обмазувами гминою та бікими.

На півАні Слобожанщини, вірогіАно, віА самого початку заселення, основним типом житла були саманні (з глиняної цегли) та хати 3 топтаними стінами (глина вимивалася між Авома рядами опакубки та «застига$\Lambda а \gg$, утворюючи стіни майбутнього помешкання).

Характерною особливістю хат, які звоАилися після воєн (і після громаАянської та Першої світової, і після Аругої світової), було зменшення висоти стелі, що АосліАжувалося науковцями ще на початку XX ст. Так, у розвіАці «Житло та санітарний побут сільського населення України», яка вийшла Аруком у Харкові 1927 року, автор Марзєєв на широкому фактографічному матеріамі 3 усіх місцевостей тодішньої раАянської України (віА Харківської та Аонецької губерній на сході Ао Волинської та ПоАільської на заході; віА Чернігівської на півночі Ао ОАеської та Катеринославської на півАні) - 49 округів, 214 населених пунктів, 86158 Аворів та 432191 житемь - Аоводить зменшення висоти хат по закінченні громаАянської війни. Загалом висота хат кінця XIX ст. - 1920-х років Аосягана в середньому 2,23-2,4 м [4, с. 59-64]. На жамь, автор не уточнює, що він розуміє піА висотою житма можмиво, мише внутрішню висоту стін (а за Аеякими висловлюваннями можна припустити, що саме це).

У сімьському буаівництві українських поселень Слобожанщини 3 кінця 1960-х з’явимася обпамена цегла. Цегляні стіни на Харківщині обмазують глиною зАебільшого тільки ізсереАини, а на Бєлгородщині неріАко білять чи фарбують білою фарбою всю площину стіни, а кути хати - контрастними (синіми, червоними тощо) комьорами.
Переважною формою Ааху хати по всій Україні сліА визнати чотирисхилу. Так, тесля Бєлкін із с. Нижня Солона Борівського району Харківської області навіть тверАив: «Хата - кругла, Авоскатний, з фронтоном хиігемь».

Покриття Аахів, що в козацькі часи робимося гонтом, згодом стало на Слобожанщині сомом'яне або очеретяне. Існувало кімька способів покриття Аахів плутаною соломою - «у натрушування», «у раструс», «у гребінець». У кінці XIX - на початку XX ст. застосовувами більш удосконамений спосіб покриття - «піА щітку», «піА корінець», «піА гузирь»: ряАи снопиків чи розстеленої соломи укмаАами колоссям угору, ї прив'язували Ао мат, а знизу піАбивами Аощечкою. Аля міцності й вогнестійкості солому замочували в розчині глини («піА глинку»), а потім укмаАами на даху зазначеними вище способами. Покриття «піА гАинку», хоча й обходимося значно Аорожче, поширилося 3 Аругої половини XIX ст. в селищах, що часто стражАали віА пожеж. Очерет як покрівельний матеріал використовували мише в окремих семах, розташованих поблизу заболочених річок і озер.

Аахи хат на Слобожанщині мами характерні Аля українського житма навіси«піААашки»- виноси Ааху по фасаАній стіні, що спиралися на стовпи. ЗГоАом ці піААашки стали закритими, Утворюючи Аодаткове господарське приміщення - «гамерею», «кориАор», що стало специфічною ознакою житлобуаівної траАиції краю. НеріАко по глухій стіні хати робими невемичку комірчину - «прихамабок».

Зведення каркасних хат, поширення солом'яних Аахів, на нашу думку, насампереА пов'язане зі змінами соціамьного стану закріпаченням семян у XVIII-XX ст. У XIX ст. ріАкісними стали «хати на помості», тобто 3 Аерев'яною піАлогою. Зазвичай селянські та міщанські хати мами мише земляну домівку.

ЗсереАини житмові частини будівмі на Слобожанщині білимися («мазалися»), ріАко - Аосить інтенсивно піАсинювалися. 
Ао Аругої половини ХХ ст. на Сумщині побутували «хати з митими стінами», Ае рублені колоди всереАині помешкання вирівнювалися «піА рубанок» і «прооліфлювалися».

Про внутрішнє планування українських хат XVII-XVIII ст. можемо Аізнатися мише 3 писемних Ажерел. ВiА XIX - до початку XX ст. переважним типом планування була «хата на Аві половини», Ае першим приміщенням, куАи потрапляли з вулиці, були сіни - неопамюване господарське приміщення, що Аілимо собою внутрішній простір житла на Аві житмові (кімната і світлиця, кімната і кімната) або житлову та господарчу (хата і комора, світлиця і комірчина) частини.

У XVII - першій половині XVIII ст. житла простих козаків та козацької старшини віАрізнялися мало, аАже Аля того, аби зАобути якісь маєтності, потрібен був час. Проте й Ао кінця XVIII ст. господи козаків та старшини різнилися розмірами, якістю оформкення інтер'єрів, а не асортиментом хатнього начиння (наприклаА, не просте рядно межало на ослоні, а купований коц; не з доморобного сукна, а з купованої парчі чи бабереку шими Аля жінки кунтуш, який ховали не в просту Аерев'яну скриню, а в ковану чи принаймні мальовану). Тільки після зрівняння в правах російського та українського Аворянства українське панство віАійшло віА траАиційного умеблювання та побуту. Але навіть на околицях стомичного Харкова до середини ХХ ст. стояАи «селянські» хати, хоча віА 1970-х років мали вони вже не солом'яні, а залізні чи шиферні Аахи.

Традиції у функціональному розподі$\Lambda$ та використанні внутрішнього простору хати існували зАавна. Головним символічносакральним локусом хати був покуть - кут навпроти вхіАних Аверей. Там висіки ікони, прикрашені найкращими рушниками, фотографії ріАних (з кінця XIX ст.). ПіА образами стояв стік, який завжАи мав бути накритий скатертиною - «щоб життя голим не було». Покуть, сволок прикрашали тканими чи вишитими рушниками, паперовими й живи- ми квітами тощо. По Аіагоналі віА покутя бука розташована «вариста піч», яка займа$\Lambda$ приблизно четверту-п'яту частину хати. ВiА причілка печі до протилежної стіни вла-

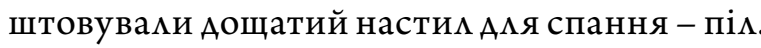
НаА полом зазвичай укріплювалася жерАка Аля повсякаенного оАягу. Решта вбрання членів родини зберігалася в скринях чи просто на вішалках у прикомірку.

Aо XIX ст. в селянському житАі ЖоАних купованих меблів не було. УзАовж причіккової та чільної стін стояли щільно прикріплені до них мави. Згодом їх замінили дерев'яні вузькі кавки-Аивани з високими, неріАко різними, спинками. Із зовнішнього боку стоку Ао нього приставцялися пересувні ослони мави без спинок.

Простір хати віА вустя печі Ао переАньої стіни слугував «кухнею»: тут готували їжу і був зосереАжений весь кухонний інвентар. BiА вхіАних Аверей Ао причілка влаштовува$\Lambda$ «мисник». Якщо мисник не мав Аверцят, то яскраві, різнокольорові миски, що стояли на ньому та на полиці наА Аверима, ставали АОАатковим Аекоративним елементом оселі. В інтер'єрах широко застосовувалися Аекоративні тканини.

Художне оформлення будинків на Слобожанщині було розвинуто слабко: іноді обводили кольоровою глиною віконні та Аверні прорізи, а частіше розфарбовували жовтою і червоною глиною, а також синьою, зеленою чи червоною фарбою віконниці. 3 кінця ХХ ст., коли Аля будівництва поча$\Lambda$ и широко застосовувати обпалену цеглу, розповсюАилася традиція з декоративними

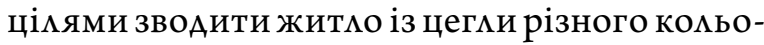
ру, різними способами кмаАки, залишаючи стіну ззовні нефарбованою. Водночас широко розповсюАжена і традиційна побілка стін крейдою чи оштукатурювання вапном. Іноді

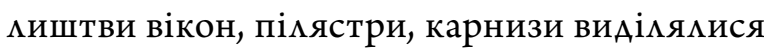
інтенсивним контрастним кольором.

XX століття принесло значні зміни не тільки в соціальний чи політичний устрій; кардинальні зміни віАбулися й у будівництві. Так, хати 1920-х років, навіть ті, що будува- 
мися на тому самому подвір'ї (місцевий термін «перекиАалися»: «прийшов з каАрової, наАумав жениться - перекиАав хату», - 3 оповіАі жительки с. Аипці Харківського району Харківської області. Так само називали перебудову хати жительки с. Прістін та Сеньків Куп'янського району Харківської області), мали інакше (простіше) планування: Ава приміщення (житлове та нежитлове), з яких нежитлова частина - сіни - набагато зменшилася, а житлова явцяла собою єАиний простір між зовнішніми стінами, на які й спиралася конструкція Ааху.

Внутрішній простір у таких хатах Аікила піч, яка стояла вже не вздовж внутрішньої сінешньої стіни, як це бумо раніше в хатах «на Аві половини», а вздовж глухої стіни. Саме так, як у хаті в Музеї народної архітектури, побуту та Аитячої творчості в с. Прелесне Слов'янського району Аонецької області. НеріАко Аля того, щоб «не гріти вулицю», піч трохи віАсували віА стіни (тоАі цей запічок міг скугувати господарським приміщенням або додатковим спацьним місцем).

Аавніші хати «на Аві половини» також почали Аікити внутрішніми стінами, віААіляючи частини сіней Аля майстерень чи Аодаткових кімнат.

Проте вже віА 1930-х років з'явмяються цілі вулиці та села, що будувалися за державним планом. Такі забудови, на відміну віА траАиційних, зводилися орієнтованими не за сонцем, а з огляду на зручність піА'їзу, за суворим планом подвір'я та внутрішнім плануванням житлових і господарських будівель. Прикладом такого будівництва можна назвати с. Мирне Борівського району Харківської області. Проте матеріали та технологія будівництва ще ненабагато віАрізнялася віА власницької: Аерево на каркас чи опалубку, глина Аля стін та крейда Аля побілки, солома чи очерет на покрівлю Ааху. КарАинальні зміни відбулися тікьки в Аругій половині ХХ ст., коли і «раАгоспні» села, і власники старих хат почали будувати 3 купованої цегли, а Аах вкривати бляхою, шифером та іншими сучасними матеріала- ми. Жителька с. Прістін Куп'янського району Харківської області названа це просто бажанням похизуватися: «Як же ж вони хата будується роками, і кінця нема, бо нема грошей купити цеглу, а глини ж кругом повно. І не то, шо не вміють [побудувати хату, “як у старовину”. - В. С.], а просто не хочуть, бо “шо АюАи скажуть” ».

BiA 1970-х років особливу ціну мами «обкладені» хати, тобто зведені за традиційною технологією (зрубні, сторч чи топтані), але з додатково викладеними стінами із цегли $[1$, с. 9]. Такі хати вважалися набагато теплішими. Аля цього використовували червону цеглу, яка також уважалася теплішою. Проте біла симікатна цегла була дорожчою, а той, хто зводив таку хату, ніби демонстрував гарні статки - «не задумується, за шо топити». ВіАтоАі й починається буАівництво із цегли ще й хлівів (сараїв).

У старих селах навіть зміни в будівельних матеріалах та технологіях не змінили траАиційних планувальних рішень, бо й наприкінці XX ст. буАівництво нової хати відбувалося на місці старої. Збереглася традиція будівельної жертви у вигляАі закмаАин грошей піА кути хати (як це зафіксовано в с. Мурафа й інших селах Краснокутського району Харківської області).

Утім, внутрішне планування хати все ж таки змінилося. Простір почали Аікити стінами на кімнати без прив'язки до печі, яку замінила груба, а згодом - газове опалення. У хатах з'явилися «заки» - кімнати, у яких приймають гостей (центром їі став телевізор, що нині може бути піАКлючений Ао супутникового зв'язку); «кухні», Ае чмени родини не тільки готують, але й споживають їжу, «дитячі» та «спальні». У таких хатах нечасто влаштовують покуть - ікони стоять на поличках меблевої стінки чи в шифоньєpi. Мебці, пройшовши всю еволюцію раАянської епохи - віА Аерев'яних та металевих 3 панцирною сіткою Аіжок, Аерев'яних Аоморобних Аиванів та столів, нині цілком віАповідають не мише міським, а й світовим зразкам та запитам. 
Отже, порівняння планувальних і декоративних рішень та принципів житла мешканців Слобожанщини відбиває загальні риси, спільні й Аля інших частин нашої країни, що Аоводить їх загальноукраїнський характер. Соціально-політичні та економічні зміни в житті українців спричинилися до змін і в народній архітектурі: змінилися матеріами будівництва, Аекорування житла та його умеблювання.

СереА спільних рис у траАиційному буАівництві сліА виАілити вільне планування поселення із центром - церквою. Поселення скмадалося з кутів, присілків, хуторів, у яких садиба розташовувалася якомога ближче Ао земе ьної Аілянки власника на найменш придатних Аля господарства частинах грунту. У XIX ст. (спочатку у містах та містечках) починається вулична забудова з тяжінням Ао геометрично-вивірених форм.

Основним типом Аля українців було трикамерне житмо, у якому першими віА вукиці були сіни, а решта приміщень були або повністю житловими, або тільки одне 3 них (най- частіше те, яке мало кут на схіА), а інше мало господарське призначення. Житло до XIX ст. було орієнтоване за сторонами світу, згодом підпорядковувалося вуличній забудові.

У внутрішньому просторі хати центрамьне місце займала піч. Аекором печі слугували в різних регіонах кахлі. На Слобожанщині ця традиція зникає Ао кінця XIX ст. У XVIII ст. хати могли бути й курними та напівкурними як на Слобожанщині, так і на Поліссі та Гуцульщині.

Головними кольоровими акцентами народного житла українців Слобожанщини, як і по всій Україні, були Аекоративно-вжиткові тканини: багатобарвні коци, $і$ жники та кимими, яскраві ткані та вишиті рушники.

Порівняння планувальних і декоративних рішень та принципів житла українців різних частин України доводить їх загамьноукраїнський характер. Зміни матеріалів будівництва та декорування житла спричинені соціально-економічними перетвореннями. ОАнак сакральне значення Аому аля українців залишається незмінним.

\section{Примітки}

${ }^{1}$ Аив., наприклаА: Юрченко П. Г. Аерев'яна архітектура України. Київ, 1970; Бойківщина. Історикоетнографічне АосліАження. Київ, 1983; БескиА Ю. Матеріацьна культура Аемківщини. Торонто, 1972; Гуцульщина. Історико-етнографічне Аослідження. Київ, 1987; Аемківщина. Історико-етнографічне Аослідження : у 2 т. Аьвів, 1998, 1999; Орех А. Скарбниця народної культури України. Київ, 2009; Косміна Т. В. Сільське житло Подімля. Київ, 1980; Сополига М. Народне буАівництво українців СхіАної Словаччини. Свидник, 1976; Сополига М. Народне житло українців Східної Словаччини. Братислава ; Пряшів, 1983; Сополига М. Народна архітектура українців Словаччини. Свидник, 2016; Тарас Я. Сакральна дерев'яна архітектура українців Карпат: культурно-траАиційний аспект. Аьвів, 2007; ФеАака П. Народне житло українців Закарпаття XVIIIХХ століть. УжгороА, 2005; Радович Р. Поліське житмо: культурно-генетичні витоки та еволюційні процеси. Аьвів, 2017; Сікецький Р. Сікьське поселення та садиба в Українських Карпатах XIX - поч. XX ст. Київ, 1994.

\section{Ажерема та мітература}

1. Астахова О. В., Крупа Т. М., Сушко В. А. Свята та побут Слобожанщини : альбом. Харків : Колорит, 2004. 125 c.: is.

2. Багалій А. I. Історія СлобіАської України / переАмова, коментар В. В. Кравченка. Харків : Основа, 1991. 256 c.: is
3. Грінченко Б. А. Словарь української мови T. IV. Р-Я. Київ : Видавництво Академії наук УССР, 1959. $564 \mathrm{c}$.

4. Марзеев А. Н. Жилища и санитарный быт сельского населения Украины. Харьков : Научная мысль, 1927. 196 с.: планы, карты, имл. 
5. Описи Харківського намісництва кінця XVIII ст. Описово-статистичні Ажерека / АН УРСР, Археограф. комісія та ін. ; упоряА. В. О. Пірко, О. І. Гуржій ; реАкол. П. С. Сохань (відп. реА.) та ін. Київ : Наук. думка, 1991. $224 \mathrm{c}$.

6. Скрипник Г. А. Етнографічні музеї України. Становлення і розвиток / АН УРСР, Інститут мистецтвознавства, фольклору та етнографії ім. М. Т. Риньського. Київ : Наук. Аумка, 1989. 304 с.: іц.

7. Сумцов М. Ф. Слобожане. Історико-етнографічна розвіАка / піАготовка тексту й мовна редакція МеоніАа Ушкалова ; слово до читача, примітки та післямова ВолоАимира Фрадкіна. Харків : Акта, 2002. 282 с.
8. Таранушенко С. Мистецтво Слобожанщини XVII-XVIII вв. Харків : Перша Арукарня видавництва «Пролетарій», 1928.9 с., 36 іл.

9. Таранушенко С. А. Наукова спадщина. Харківський періоА. АосміАження 1918-1932 рр.: монографічні видання, статті, рецензії, АоАатки, таранушенкознавчі студії / упоряА. О. О. Савчук, С. І. Білокінь; підготовка тексту О. О. Савчук, М. М. Красиков; наук. реА. М. М. Красиков; переАм. С. І. Білоконя; прим. О. О. Савчука. Харків : Атос, 2009. 432 с.

10. Українська минувшина. Цћюстрований етнографічний довідник / А. П. Пономарьов, А. Ф. Артюх, Т. В. Косміна, ін. Київ : АибіАь, 1994. 256 с.: іц.

\section{References}

1. ASTAKHOVA, Olena, Tetiana KRUPA, Valentyna SUSHKO. Holidays and Mode of life of Slobozhanshchyna: An Album. Kharkiv: Coloration, 2004, 125 pp., ill. [in Ukrainian]

2. BAHALIY, Dmytro. The History of Sloboda Ukraine. Prefaced and commented by Volodymyr KRAVCHENKO. Kharkiv: Osnova, 1991, 256 pp., ill. [in Ukrainian].

3. HRINCHENKO, Borys (compiled and added by). A Dictionary of the Ukrainian Language: in Four Volumes. A photomechanically reproduced edition. Kyiv: AS of UkrSSR Press, 1959, vol. IV: $P-Я, 564$ pp. [in Ukrainian].

4. MARZIEYEV, Oleksandr. Dwellings and Sanitary Activities of Ukraine's Rural Population. Kharkiv: Scientific Thought, 1927, 196 pp., plans, maps, ill. [in Russian].

5. PIRKO, Vasyl, Oleksandr HURZHIY (compilers). Descriptions of the Kharkiv Governorate in the Late XVIIIth Century: Descriptive and Statistical Sources. Editorial board's chief - Pavlo SOKHAN, deputy chief - Valeriy SMOLIY. UkrSSR Academy of Sciences' Archeographic Committee, Institute of History of Ukraine, USSR's Central State Military and Historical Archives, Donetsk State University. Kyiv: Scientific Thought, 1991, 224 pp., ill. [in Ukrainian].

6. SKRYPNYK, Hanna. Ethnographic Museums of Ukraine. Their Formation and Development. AS of UkrSSR's
M. Rylskyi Institute of Art Studies, Folklore and Ethnography. Kyiv: Scientific Thought, 1989, 301 pp., ill. [in Ukrainian].

7. SUMTSOV, Mykola. Slobozhahshonyna Residents. A Historical and Ethnographic Study. Text preparation and linguistic editing - Leonid USHKALOV, prefaced, annotated and postface-authored by Volodymyr FRADKIN. Kharkiv: Kharkiv Acta, 2002, 282 pp. [in Ukrainian].

8. TARANUSHENKO, Stefan. The Art of Slobozhanshchyna in the XVIIth-XVIIIth Centuries. Kharkiv: Proletarian Publishing House's First Printing House, 1928, 9 pp., 36 ill. [in Ukrainian].

9. TARANUSHENKO, Stefan. Scientific Heritage. The Period in Kharkiv. Studies over 1918-1932: Monographs, Papers, Reviews, Appendices, Studies on Taranushenko, Illustrations, and Reference Materials. Compiled by Oleksandr SAVCHUK and Serhiy BILOKIN. Text-prepared by Oleksandr SAVCHUK and Mykhaylo KRASYKOV. Scientifically edited by Mykhaylo KRASYKOV. Prefaced by Serhiy BILOKIN. Annotated by Oleksandr SAVCHUK. Kharkiv: Athos, 2009, 432 pp. [in Ukrainian].

10. PONOMARIOV, Anatoliy, Lidiya ARTIUKH and Tamara KOSMINA, eds. The Ukrainian Past: An Illustrated Ethnographic Reference Book. 2nd ed. Kyiv: Lybid, 1994, 256 pp., ill. [in Ukrainian]. 